\title{
God, Evolution, and the Body of Adam
}

\author{
KENNETH W. KEMP \\ University of St. Thomas \\ St. Paul, Minnesota \\ KWKemp@StThomas.edu \\ ORCID: 0000-0001-7436-8746
}

\begin{abstract}
Catholic evolutionists have proposed to reconcile evolutionary anthropogenesis with Catholic doctrine by suggesting that a created soul could be infused into a body produced (in part, if not wholly) by evolution from an animal body. Could such an infusion yield not just a Platonic composite but a being with the unity of substance required by a Thomistic philosophy of nature? How could such a soul be the form of the body into which it was infused?

This paper suggests that animals seem to have sense-powers with a level of complexity, if not sufficient to underlie the abstraction of concepts in a being that also has a rational soul, then at least nearly so. The burden of proof lies rather on those who think that evolutionary development of such powers is not possible.

In its final section, the paper argues that the existence of Eve as a second, and the only additional, initial rational being does not create special problems for the view here articulated.
\end{abstract}

Keywords: anthropogenesis; Eve; ethology; infusion of the soul.

ScientiaetFides $8(2) / 2020,139-172$ 


\section{Introduction}

The idea that man has an animal ancestry predates Charles Darwin's evolutionary ideas by a half-century. It was explicitly articulated in both of the major works of early nineteenth-century evolutionism-Jean-Baptiste de Lamarck's Philosophie Zoologique (1809) and Robert Chambers' Vestiges of the Natural History of Creation (1844). Darwin made only three passing references to human origins in On the Origin of Species (1859), ${ }^{1}$ but the implication of animal origins was there and no one missed it. Oxford's Anglican bishop Samuel Wilberforce, in an (anonymous) review of the Origin, wrote that "if Mr. Darwin can [...] demonstrate to us our fungular descent, we shall dismiss our pride, and avow, with the characteristic humility of philosophy, our unsuspected cousinship with the mushrooms" $(1860,121)$. By the time Darwin published The Descent of Man in 1871, three more books explicitly defending evolutionary anthropogenesis had already been published-Thomas Henry Huxley's Evidences as to Man's Place in Nature (1863); Carl Vogt's Vorlesungen über den Menschen: Seine Stellung in der Schöpfung und in der Geschichte der Erde (1863), an English translation of which (as Lectures on Man: His Place in Creation and in the History of the Earth) was published the following year; and Giovanni Canestrini's Origine dell'uomo (1866).

Although many Catholics, evolutionist and anti-evolutionist alike, denied that theories of evolutionary phytogenesis or zoögenesis, whether true or false, have any theological significance, ${ }^{2}$ the same was surely not true of the question of whether evolutionary processes played a role in anthropogenesis.

1 In the final chapter of On the Origin of Species he wrote: "Light will be thrown on the origin of man and his history" $(1859,488)$. He had already hinted at this earlier in the book-"All vertebrate animals having true lungs have descended by ordinary generation from an ancient prototype" $(1859,191)$. The final chapter makes a stronger claim: "I should infer from analogy that probably all the organic beings which have ever lived on this earth have descended from some one primordial form, into which life was first breathed" $(1859,484)$.

2 To cite just one example, Oratorian priest Pierre-Julien Hamard wrote in his article for the Dictionnaire apologétique de la foi catholique that "The Bible grants equal freedom to transformists and to the defenders of successive creations. [...] Whenever it is not absolutely explicit, [...] anyone who invokes its authority puts at risk both the Bible itself and the religious cause of which it is the support” $(1889,3093)$. 


\section{Historical Background}

\subsection{Catholic Objections to Evolutionary Anthropogenesis}

The first official Catholic notice of the idea of evolutionary anthropogenesis came at a provincial council held in Cologne in the spring of 1860. In the context of a much more general review of Catholic doctrine on points ranging from the Trinity to the theology of nature, it declared that "Our first parents were made [conditi] immediately by God. Therefore, clearly opposed to Sacred Scripture and to faith is the opinion [...] that man, even considering only his body, was brought forth by the spontaneous change [immutatio] of a less perfect nature into a more perfect one in a way that is continuous and culminates in a human nature" (Cologne, 1860, I.IV.14 (= col. 292)). Although one might think that, coming the year after the publication of Darwin's Origin, the Council's statement was responding to that book, there are good reasons for thinking that that is historically incorrect. First, Heinrich Georg Bronn's German translation of the Origin was only being published as the Council met. ${ }^{3}$ Second, that translation, as its very title (Über die Entstehung der Arten im Thier- und Pflanzenreich ...) shows, minimized the relevance of the book to anthropogenesis. Finally, there is a more likely target-Chambers' Vestiges, Vogt's German translation of which had been published in 1851 with a second edition released in 1858 . Chambers $\left(1844,326\right.$; Vogt, 1858, 276) ${ }^{4}$ seems to have suggested precisely the kind of mixed (evolutionary-creationist) account of anthropogenesis rejected by the Council. I will return to Chambers' ideas below.

Whether the doctrine articulated at Cologne precludes any evolutionary account of the origin of the human body, as some Catholic anti-evolutionists have been insisting now for 160 years, or whether it is more narrowly focused on continuist, non-providentialist, and non-exceptionalist versions of evolutionary anthropogenesis, is a question that we can set aside here. A comprehensive rejection of any form of such anthropogenesis surely was

3 The Council met from 29 April to 17 May 1860. Heinrich Georg Bronn's translation came out in three parts-on 4 April, 2 May, and 11 June 1860 (Börsenblatt 1860).

4 Vogt translated the sixth edition, but that does not affect the relevant passage. 
the view of many Catholic theologians. Early on, some theologians claimed that the evolutionary view was heretical $; 5$ by the turn of the century, the more common evaluation was that the idea was merely rash. ${ }^{6}$

What concerns did Catholic anti-evolutionists have about evolutionary anthropogenesis? Surely part of the problem was created by the fact that evolutionary ideas generally kept bad company-Karl Vogt, Thomas Henry Huxley, Clémence Royer (Darwin's first French translator), and Ernst Haeckel (Darwin's most prominent German promoter) divided their time between arguing for evolution and denying traditional Christian theological doctrines.

There were, however, also more focused theological concerns. First, Catholic anti-evolutionists were generally insistent that evolutionary anthropogenesis was in ineliminable tension with the text of Holy Scripture and with the interpretation of the relevant passages of Scripture found in the Fathers. To be sure, St. Augustine had cautioned against excessive anthropomorphism in the reading of the very text at the center of the controversy:

To think that God molded [ finxit ${ }^{7}$ ] man from the slime of the earth with bodily hands is childish. [...] Anyone in his right mind understands that the name of a bodily member [in passages in which one is found] is used for the power and

5 Matthias Joseph Scheeben (1873-1887, II:144) wrote: "It would already be heretical if one hypothesized only a bodily 'descent of man from the apes' on the way to a gradual transmutation of forms, even if one added divine creation of the soul on completion of the transmutation."

6 Erich Wasmann, S.J., $(1906,443)$ wrote that "God could make use of matter previously prepared by natural causes [...] we may assume to be possible", but added in a footnote that a great majority of theologians still held to the union of the human soul with a body formed from inorganic matter "in light of a constant tradition and the statements of the ordinary magisterium" and that "theologians cannot be faulted for retaining the literal interpretation [...] until the other side offers satisfactory evidence that the text should be interpreted differently" (1906, 444, emphasis added). That italicized phrase captures precisely the technical theological conception of rashness. (Translations mine; for the published translation, see 1923, 436-7.) See also Buonpensiere, 1898, 40-41.

John Cuthbert Hedley (1898) (then a Benedictine priest, but later Bishop of Newport (Wales)) gave a cautiously sympathetic review of Zahm's Evolution and Dogma.

7 Augustine was evidently looking at the Vetus Latina translation, which uses finxerit where the Vulgate has formavit. 
might of God. [...] Man's pre-eminence lies [...] in the fact that God made him to His own image. $(415,6.12 .20-21)$

One should not, said St. Augustine, take finxit, a word that has a strong connotation of working with one's hands, so literally. Catholic evolutionists thought the same thing about limus (slime). They might have said

To think of God as making man directly from the slime of the earth underestimates the reach of secondary causes. [...] Anyone who is knowledgeable of the facts uncovered by modern science would see that the phrase "slime of the earth" has been used in this passage to mean matter generally.

Catholic anti-evolutionists may not have demanded literal slime, but they were certain that the word excluded animal bodies. This hermeneutical question will not be explored further here.

A second concern was that Adam's descent from animals seemed to offend against the dignity of man. In what is perhaps the last major work of Catholic anti-evolutionism, Ernesto Cardinal Ruffini wrote, "Who will be ready to believe that Adam had for his father and mother two brute beasts? Although innocent and holy, he would certainly have been in a much less honorable condition than is ours" ([1948] 1959, 139). This persistent concern received an early reply from Filippo De Filippi (whom I will introduce later). In an appendix to the published version of his 1864 lecture "L'Uomo e le scimie," he wrote: "To think that the origin of man is perhaps less divine when the Biblical clod of earth turns out to be the entire organic world is a strange way of understanding human dignity" $(1865,69)$.

Some Catholics articulated a third concern, which the Jesuit philosopher Charles Boyer expressed as follows: "Let us suppose that some animals have reached the limits of the sensible order. I say: they would not be able to generate [donner origine] a human body" (1952, 204) and "Only bodies animated by an intellectual [spirituel] soul can engender bodies capable of being animated by an intellectual [spirituel] soul” (1952, 205). It is this philosophical objection that will be the particular focus of this paper. 


\subsection{Catholic Openness to Evolutionary Anthropogenesis}

Not all Catholics shared the views articulated at Cologne, however. St. John Henry Newman, for example, wrote in his notebooks:

it is as strange that monkeys should be so like men, with no historical connexion between them, as [...] the notion that there was no course of facts by which fossil bones got into rocks. [...] I will either go the whole hog with Darwin, or, dispensing with time \& history altogether, hold, not only the theory of distinct species but that also of the creation of fossil-bearing rocks. $(1969-1970,158)$

Catholic philosophers, scientists and theologians-from de Filippi and St. George Mivart through Zeferino Cardinal González, Dalmas Leroy and John Zahm to Henry de Dorlodot and Ernest Messenger-over the course of the next eighty years offered defenses, if not in every case of the fact of evolutionary processes playing a role in the formation of the first human body, then at least of the compatibility of that idea with Catholic theology. By the end of the nineteenth century, two Catholic alternatives to the view that God formed Adam's body from the slime of the earth, or (in a more polite version) from dust-in any case from עפר 'afar-had emerged.

\section{Outline of the Task: Constraints on a Catholic Evolutionism}

To answer the question of whether it is possible to integrate the idea of an evolutionary origin of the human body into a more comprehensive Catholic account of anthropogenesis we must begin by exploring some background considerations, constraints that an acceptable solution must satisfy. What evolutionary processes are (according the best scientific evidence) available? What kind of being (according to Catholic anthropology) do they have to produce?

\subsection{Evolutionary Processes}

The transformative processes in question would be the genetic mutations that effect something new in an individual animal and a process (such as 
natural or sexual selection, or the founder effect) that spreads this change through an entire population. ${ }^{8}$ That the mutations would be biologically random does not preclude its subsumption under Divine Providence.

To these processes, one can, of course, add what Darwin called the Correlation of Growth, a kind of accidental selection:

the whole organisation is so tied together during its growth and development, that when slight variations in any one part occur, and are accumulated through natural selection, other parts become modified. $(1859,143)$

there are many unknown laws of correlation of growth, which, when one part of the organisation is modified through variation, and the modifications are accumulated by natural selection for the good of the being, will cause other modifications, often of the most unexpected nature. $(1859,85-86)$

\subsection{Catholic Anthropology}

What doctrines must an account of evolutionary anthropogenesis accommodate if it is to remain consistent with Catholic theology?

The first doctrine is that man is a composite of a material body and a rational soul which is "truly in itself and essentially the form of the human body." That doctrine was articulated at the Council of Vienne (1312), and again at Lateran V (1513). ${ }^{9}$ Although Catholic anthropology is quite explicitly non-materialist, it is also opposed to the dualism that is a central feature of Platonism. Not only is the soul not a prisoner in a corporeal prison, it is not even the pilot of a ship or (though Gilbert Ryle's image is perhaps vaguer) a ghost in a machine $(1949,22)$. St. Gregory of Nyssa, in objection to the idea of the transmigration of souls, wrote that:

8 As an historical matter, we might bear in mind that many Catholic evolutionists, in the first half-century of the Catholic discussion of this question, would have identified the operative processes as some internal factor, a component of a broader orthogenetic theory. Here I will focus rather on the random mutations and selective filters that play the predominant role in evolutionary change according to current evolutionary theory.

$9 \quad$ See also de Dorlodot, 1903. 
Some people think that one and the same soul becomes successively that of a man and that of an irrational being, changing bodies and forever passing, as it pleases, from one to another-from man to bird, or to fish, or to beast, and then back to man. Some people extend this nonsense even to bushes. [...] Those who think that that soul migrates from one species to another [...] neglect to make a distinction among the distinctive features of the various species, mixing everything with everything else-the irrational and the rational, the sensible and the insensible. [...] To say that one and the same soul, now rational and intellectual because it has our kind of body, could then lie in a hole with the snakes, or flock with the birds, or [...] live underwater, or become something not even capable of sensation [...] is nothing other than to think that everything has the same nature. (380, PG 108-9)

What are the implications of that doctrine for our question?

Ernest Messenger, the Catholic priest who wrote the most comprehensive theological defense of Catholic evolutionism, cited a Scholastic formula (which he attributed to St. Gregory of Nyssa) that "the nature of the soul is always proportional to the body." Messenger put the point as follows: "the human soul [...] cannot inform a body which is not human, that is, one which does not possess what is essential for a human organism, or more particularly, one which does not possess the organs which are the essential seat of the higher organic faculties, or which does not possess the specific organization peculiar to these organs" $(1932,87)$.

The second doctrine, that every individual human soul (and a fortiori the first) was directly created by God, was the prevailing view among Catholic theologians. The question of whether to define the creation of human souls as Catholic doctrine had been raised at Vatican I in response to the traducian alternative that had been advanced by Jakob Frohschammer and Bl. Antonio de Rosmini-Serbati earlier in the century. ${ }^{10}$ The proposal met with some resistance ${ }^{11}$ and the matter had not been resolved before the fall of Rome

10 Frohschammer 1854 and Rosmini-Serbati 1858, §§647-659. Frohschammer’s book was placed on the Index of Prohibited Books in 1857. Rosmini's work was reviewed by the Holy Office in 1854 , but no formal censure of his view was then made.

11 There is a long note explaining why the commission did not include the idea that the soul was directly created by God in one of the schemata prepared at the First Vatican Council (1869). 
and the prorogation of the Council. Nevertheless, the creation of the soul was accepted by Catholic evolutionists and anti-evolutionists alike and played no role in Catholic controversy over evolution and anthropogenesis. The question of the origin of the human body was standardly treated as a distinct question in theology textbooks addressing the topic of creation.

The third doctrine is that human beings and animals are different not just in degree, but in kind. There is, to use the words of St. John Paul II, an "ontological discontinuity" between the two. As signs of distinctively human being, he mentions "metaphysical knowledge, self-consciousness, moral conscience, freedom, and aesthetic and religious experience." These signs, John Paul went on to say, must be subjected to philosophical analysis (1996, para. 6). At their root, on the traditional Catholic analysis, is rationality-the powers of intellect and will, and their acts (on the speculative side: concept-formation, judgment, and inference; and on the practical side: intention and choice).

The idea that man can apprehend concepts as well as perceptual images while animals, by contrast, cannot can be illustrated by three examples. J. R. R. Tolkien put it this way: "The human mind [...] sees not only greengrass, discriminating it from other things [...], but sees that it is green as well as being grass" $(1966,22)$. René Descartes illustrated the human faculty of conceptualization (in contrast to the imagination which is to some extent within the reach of animals) this way in Meditation Six: "When I imagine a triangle I don't merely understand that it is a three-sided figure, but I also see the three lines with my mind's eye as if they were present to me; [...] if I think of a chiliagon, although I understand quite well that it is a figure with a thousand sides, I don't imagine the thousand sides or see them as if they were present to me" (1641 [1931], 185-6). Finally, a few months ago, the Congo's Virunga National Park posted an amusing picture of two gorillas imitating the posture of one of the park's rangers. Innocent Mburanumwe, deputy director of the park, explained the behavior by saying that, since the gorillas had been raised by the rangers, "they are considering that those rangers are their parents" (Bever 2019). It was a reasonable explanation, but, of course, no one thinks that gorillas really have the concept "parent," something of which they recognize other instances. 


\section{Three Versions of Anthropogenesis}

I said a moment ago that two Catholic versions of evolutionary anthropogenesis had emerged by the end of the nineteenth century. Adding those to the ordinary version, we can distinguish three families of theories.

\subsection{Family № 1: The Darwin-Chambers Family}

The first family encompasses theories in which evolutionary processes are sufficient to account for the origin of the human race. There are important differences between the evolutionary views of Robert Chambers and Charles Darwin, but they share the idea that evolutionary processes of the kind that gave rise to new species of plants and animals were fully capable of producing human beings from other animal species. These accounts of man and his origins are inconsistent with Catholic doctrine on two points.

The first point of contradiction is the body-soul composition of the human person. Darwin, following his usual practice of avoiding theological and metaphysical questions, seldom used the word "soul." Near the end of The Descent of Man, however, he acknowledged that "He who believes in the advancement of man from some low organised form, will naturally ask how does this bear on the belief in the immortality of the soul" (1871, 2:395). ${ }^{12}$ He contented himself, however, in his reply, with denying that there is anything particularly irreligious about his theory and did not address the question of the existence of human souls.

Chambers, some years earlier, had addressed the question, writing:

There is, in reality, nothing to prevent our regarding man as specially endowed with an immortal spirit, at the same time that his ordinary mental manifestations are looked upon as simple phenomena resulting from organization, those of the lower animals being phenomena absolutely the same in character, though developed within much narrower limits. $(1844,326)$

12 Darwin used the word "soul" only a few times in The Descent of Man, and only in this one passage in a way relevant to our topic. 
So, according to Chambers, souls there may be, though not the kind of souls that constitute the ground of distinctively human powers. Chambersian souls, not being the form of the human body, are less than what is required by Catholic doctrine.

The second point of contradiction is on the question of human exceptionalism. In The Descent of Man, Darwin said "there is no fundamental difference between man and the higher mammals in their mental faculties" (1871, 1:35). Anti-exceptionalism, if not essential to Darwin's scientific project (the defense of common ancestry and natural selection), ${ }^{13}$ was important to many Darwinists' philosophical project. The importance of this thesis to the larger (i.e., extra-scientific) project of many evolutionists is suggested by two comments of Stephen Jay Gould on the difference between Darwin and Alfred Russel Wallace with respect to the origin of the human race: "If Darwin had been distressed by his failure to impress Wallace with sexual selection, he was now positively aghast at Wallace's abrupt about-face at the finish line itself" and "[Wallace] abandon[ed natural selection] at the most crucial moment of all” $(1980,53)$. What could it mean to call the purely evolutionary origin of man, rather than, say, "the truth about the origin of man," "the finish line"?

The thesis of endowed immortal spirits might appear to make Chambers' view an exceptionalist one, but it does so only at the cost of introducing a dualism inconsistent with the doctrine of Vienne. Chambers is quite clear (if not always entirely consistent) in asserting that, with respect to human powers (including mental powers), there is no difference in kind between man and animal:

The difference between mind in the lower animals and in man is a difference in degree only; it is not a specific difference. $(1844,335)$

The grades of mind [...] are mere stages of development. In the humbler forms, but a few of the mental faculties are traceable. [...] In man the system has arrived at its highest condition. $(1844,347)$

13 If animals had plants as ancestors (despite the difference in kind between the two kingdoms), why could human not have animal ancestors? 
So, the "immortal spirit," if it exists, seems at best to be something merely inserted into the human body, without itself giving that body any of the powers that are part of human nature.

\subsection{Family № 2: The DeFilippi-Mivart Family}

Catholic evolutionists were explicitly exceptionalist. Catholic evolutionism could also easily accommodate the second of the doctrines mentioned above, the direct creation of each human soul. How that creationism (about the soul) can be combined with the first doctrine (the human person as a hylomorphic composite of body and soul), however, requires careful consideration. The infusion of a created rational soul into a body which evolved from animal ancestors might raise no problems for a Platonist, but would it not be, in the words of St. Gregory of Nyssa, "a soul adapted to a strange building” (379, 29.7)? Could a Catholic accept the combination of evolution and infusion? Could a Thomist? Some Catholics thought that they could. Two Catholic biologists, Filippo De Filippi and St.-George Jackson Mivart, articulated a version of anthropogenesis combining an evolved human body with a soul that is the locus of distinctively human powers in a way that it is not for Chambers.

De Filippi (1814-1867) was one of the leading Italian naturalists of his day. His research ranged from parasitic worms and the embryology of fish to paleontology and mineralogy. ${ }^{14}$ Professor of zoölogy and director of the zoölogical museum at the University of Turin, he also found time for both popular science writing and for reflection on the relationship between science and religion. He was a sincere and practicing Catholic. His 1864 lecture "L'Uomo e le scimie" did much to launch the debate over Darwinism in Italy.

Mivart was an English anatomist and systematic zoölogist. Originally a student of Huxley and a member of the Darwin circle, he gradually developed an evolutionism of his own. His view was, of course, controversial, but not so much so as to prevent Henry Cardinal Manning from recommending

${ }_{14}$ For a bibliography, see Moleschott 1866-67, 444-453. 
that Mivart receive an honorary doctorate from the Vatican. That recommendation was accepted by Pope Pius IX, and the degree awarded, in 1876.

Both de Filippi and Mivart were evolutionists in the sense that they accepted the idea that the origin of species lies in the transformation of other species. They differed, however, on one scientific point. De Filippi accepted a prominent role for natural selection; ${ }^{15}$ Mivart, by contrast, did not, attributing evolutionary development rather to "natural laws, for the most part as yet unknown" $(1871,305)$. That difference is not, however, important for our purposes.

This account of anthropogenesis was most explicitly presented by Mivart in his On the Genesis of Species in 1871. Its key idea is the evolution of a suitable body followed by the infusion of a created soul:

Scripture [...] says that "God made man from the dust of the earth, and breathed into his nostrils the breath of life.” This is a plain and direct statement that man's body [...] was evolved from preëxisting material (symbolized by the term "dust of the earth"), and was therefore [formed] by the operation of secondary laws. $(1871,300)$

The soul of every individual man is [...] created [...] produced by a direct or supernatural act, and, of course, [...] by such an act the soul of the first man was similarly created. $(1871,295)$

The contrast with Chambers becomes more explicit in a passage in which Mivart wrote:

We find a perfect harmony in the double nature of man, his rationality making use of and subsuming his animality; his soul arising from direct and immediate creation, and his body being formed at first (as now in each separate individual) by derivative or secondary creation, through natural laws. By such secondary creation [...] all the various kinds of animals and plants have been manifested on this planet. $(1871,287)$

15 On natural selection, see in particular de Filippi 1864, 12 and 59-60. On common ancestry, to pick just two passages, pages 43 and 51. (Citations other than those to the Appendix, will be to this 1864 edition.) 
Chambers can say no more than that a soul is inserted into a human body; for Mivart, a soul is infused into a body. It is not merely an endowment but a substantial form.

There is no doubt that Mivart was an exceptionalist, but de Filippi, less explicit about infusion, was particularly explicit about exceptionalism. Let us begin with his point that "to say that man is descended from an ape [scimia] is to do no more than to express an anatomical fact” $(1864,42)$. It is perhaps too easy to read his statement with an emphasis on the word "fact." It would express his larger view equally well (perhaps better) if the emphasis were put rather on the word "anatomical." De Filippi's second point, and in his view one even more important than the first, was that there is more to man than anatomy. The correspondences between man and ape with respect to structure are of less significance than the differences at the level of instinct and intellect.

The more we reduce the physical inequalities between man and ape, the more the inequalities that remain, the differences in powers [differenze virtuali], grow in importance [...] The place of man in nature must be determined not by the more or less of morphological characteristics subject to variation within the narrow confines of a species but by comparison of the powers proper to man with those of animals. $(1864,45-46)$

De Filippi emphasized those differences:

The naturalist who thinks he can resolve the question of whether the difference between instinct and reason, or between animal and human reasoning, by asserting that man and animal have the same power [principio virtuale], or that there is nothing in one that is not in the other, will see common sense advancing against him like a heavy phalanx, and will have to cede the field of battle. $(1864,47)$

The differences that everyone recognizes, he said, are sufficient to justify the establishment of a separate human kingdom, alongside those of minerals, plants, and animals: "The legitimacy of that kingdom cannot be disputed. Those who accept it and those who reject it both confirm it: [...] for of all of 
man's distinctive attributes, two are the most certain: one is that of putting himself in question and the other is the struggle with his own feelings" $(1864,50)$. The coat of arms of the human kingdom, he said in the last words of his lecture, contains the double crown of the moral and the teleological order $(1864,53) .{ }^{16}$

\subsection{Family № 3: The Wallace-González Family}

We must also, however, distinguish a third view, not as fully evolutionary even as the de Filippi-Mivart view. On this view, the human body is partially, but only partially, the product of evolutionary processes. That view was elaborated in one way by (the non-Catholic) Alfred Russel Wallace and in another by Zeferino Cardinal González (1831-1894).

Wallace, co-discoverer of the principle of natural selection, differed with Darwin in several respects. First, Darwin was not as absolute a selectionist as was Wallace. In the last words of the introduction to the Origin of Species, he had written, "I am convinced that Natural Selection has been the main but not exclusive means of modification." ${ }^{17}$ Wallace thought that natural selection "ha[d] probably sufficed to produce all the varieties of structure, all the wonderful adaptations, all the beauty of form and of colour, that we see in the animal and vegetable kingdoms" (1870, 332).

In 1869-70, in an anonymous review of the tenth edition of Charles Lyell's seminal Principles of Geology, Wallace indicated a second difference. He argued, briefly there, and later in more detail in "The Limits of Natural Selection as Applied to Man," the final chapter of his Contributions to the Theory of Natural Selection, that natural selection was not sufficient to

16 The teleological order to which he referred is an extrinsic teleology, the suitability of the planet for human life.

17 Italics mine. See also Darwin's comment in the conclusion of the sixth and final edition of the Origin: "as my conclusions have lately been much misrepresented, and it has been stated that I attribute the modification of species exclusively to natural selection, I may be permitted to remark that in the first edition of this work, and subsequently, I placed in a most conspicuous position-namely, at the close of the Introduction-the following words: 'I am convinced that natural selection has been the main but not the exclusive means of modification'” $(1872,421)$. 
produce several important human features. ${ }^{18}$ With respect to the mind, he wrote: "[Primitive peoples] possess a mental organ beyond their needs. Natural Selection could only have endowed savage man ${ }^{19}$ with a brain a little superior to that of an ape, whereas he actually possesses one very little inferior to that of a philosopher" $(1870,356)$. What are those human faculties "of no possible use to man in his early stages" and thus beyond the reach of natural selection? Wallace mentioned "the capacity to form ideal conceptions of space and time, of eternity and infinity [...] [and] abstract notions of form and number which render geometry and arithmetic possible” (1870, 351). He then asked:

How could "natural selection," or survival of the fittest in the struggle for existence, at all favour the development of mental powers so entirely removed from the material necessities of savage men, and which even now, with our comparatively high civilization, are, in their farthest developments, in advance of the age, and appear to have relation rather to the future of the race than to its actual status? $(1870,352)$

In other words,

in his large and well-developed brain [primitive man] possesses an organ quite disproportionate to his actual requirements-an organ that seems prepared in advance, only to be fully utilized as he progresses in civilization. [...] [W]e must therefore admit, that the large brain he actually possesses could never have been solely developed by any of those laws of evolution, whose essence is, that they lead to a degree of organization exactly proportionate to the wants of each species, never beyond those wants. $(1870,343)$

Darwin contented himself with trying to show that animals had inchoate versions of all allegedly distinctive human traits and with emphasizing

18 In his review of Lyell's book, he mentioned "the brain, the organs of speech, the hand, and the external form of man" (Wallace 1869, 391).

19 It is important to note that by "savages," Wallace meant primitive or uncivilized peoples, the term not yet having been restricted to the pejorative sense characteristic of more recent usage. 
the power of sexual selection. This brings us to a third difference between Wallace and Darwin. Wallace was a spiritualist and that served him as the foundation of an alternative explanation of the origin of the human body: "The brain of prehistoric and of savage man seems to me to prove the existence of some power, distinct from that which has guided the development of the lower animals through their ever-varying forms of being” $(1879,343)$. He later called this power "a superior intelligence" and drew an analogy to artificial selection: "[it] has guided the development of man in a definite direction, and for a special purpose, just as man guides the development of many animal and vegetable forms" $(1879,359)$. This is still, however, a "direct[ion of] the action of the laws of variation, multiplication, and survival," not a suspension of them. In his concluding remarks, he added that his theory

merely shows, that the laws of organic development have been occasionally used for a special end, just as man uses them for his special ends; [...] the law of "natural selection" can[not] be said to be disproved, if it can be shown that man does not owe his entire physical and mental development to its unaided action, any more than it is disproved by the existence of the poodle or the pouter pigeon, the production of which may have been equally beyond its undirected power. $(1879,370)$

Wallace also thought that there was a spiritual aspect of human beings, though in this he was essentially a dualist:

"spirit" is the essential part of all sensitive beings whose bodies form but the machinery and instruments by means of which they perceive and act upon other beings and on matter. It is spirit that alone feels, and perceives, and thinks-that acquires knowledge and reasons and aspires-though it can only do so by means of and in exact proportion to the organisation it is bound up with. It is the spirit of man that is man. [...] At death it quits the body for ever. $(1875,100-101)$

González articulated, though he did not explicitly endorse, a more Catholic version of this third line of evolutionary anthropogenesis. Wallace developed his version in response to what he perceived to be the scientific problems of 
what Darwin was about to defend in the Descent of Man; González developed his version as a response to Mivart, whose views, though they could not be said to be contrary to Catholic doctrine, nevertheless had, González thought, grave drawbacks-philosophical, scientific, and exegetical. He proposed consideration of an alternative:

juxtaposition of Mivart's hypothesis with a possibility noted by St. Thomas, regarding the possibility that causes or agents other than God intervened in the formation of Adam's body, that is to say, in its preliminary preparation up to an imperfect stage of development, reserving the final stages of its preparation to receive a rational soul to divine action. In this way, the essence of Mivart's hypothesis is preserved, with due regard to the direct and immediate action of God in the formation of the body of the first man, action which traditional Biblical exegesis seems to require. (1892, I:514-515)

Although the idea that natural processes could not produce a human body might lead (as it had for Wallace) to the search for a preternatural alternative, the idea could be based on other grounds. Perhaps God supplemented natural processes with direct divine action in the formation of the human body not because there was no natural way to produce a human body, but for some other reason. After all, He turned water into wine at Cana, not because the wine-sellers were out of stock, but because his mother asked him to do so. Closer to our subject, the Virgin Birth might be explained as fitting rather than absolutely necessary. ${ }^{20}$ In any case, if, as Catholic anti-evolutionists claim, Scripture tells us that God played a direct role in the formation of the first human body, then that is what He did, whether we can identify His reason for doing so or not. In addition, as Wallace pointed out, to say that a superior intelligence played a direct role in the formation of the human body is not to say that secondary causes did not play any role at all.

The Wallace-González family is clearly distinct from the views of those Catholic (and other) anti-evolutionists who believe that God formed the body of Adam directly from the slime of the earth.

20 See Aquinas, 1273, 3a, 28.1, where he argues that Our Lady's virginity is “fitting," though he does not explicitly deny that it is necessary. 


\section{A Catholic Appraisal of the Three Alternatives}

Can Filippian-Mivartist views be sustained against the objection raised by Boyer? Would the infusion of rational souls into an animal body, like the transmigration rejected by St. Gregory, also be a case of putting a rational soul into a strange building? If not, can we at least fall back on the alternative view of Wallace and González that the human body is partially, but only partially, the product of natural processes?

Let us begin with the stronger view. Can evolutionary processes, in particular mutation and selection, produce and perpetuate bodies capable of laying the perceptual foundations for conceptual thought, i.e., bodies into which rational souls can be infused? We can ask, that is to say, whether natural processes can get as far as de Filippi and Mivart require that they go.

Two things are clear. First, that one natural process can produce bodies with perceptual powers sufficient to underlie rational thought, namely human zygosis and embryogenesis. Second, that, the sense-powers of some animals being more complex than those of others, evolutionary processes must (though I will not defend the point here) be capable of producing organisms with comparatively complex internal sense powers from organisms with comparatively simpler ones-for example, mammals from reptiles. If intellectual thought requires a created soul, then the question is not whether evolutionary processes can turn a merely perceptual species into an intellectual one. It is rather merely whether evolutionary processes can turn a species with internal perceptual powers insufficiently complex to underlie the abstraction of concepts (earthworms and gnats, if not also donkeys and cats) into one whose internal perceptual powers are sufficiently complex to allow such abstraction.

Let us abstract from an admittedly more complex reality a linear progression:

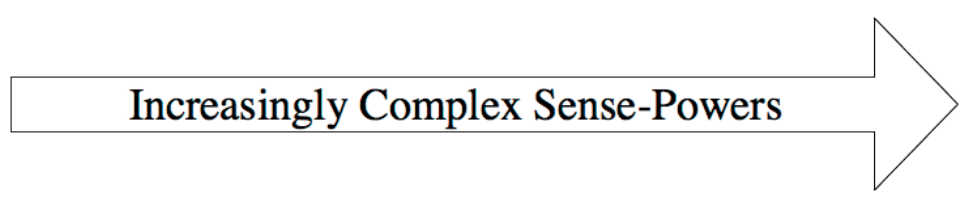

ScientiaetFides $8(2) / 2020$ 
On this continuum, we need to focus on two points-the minimum level of complexity necessary for the abstraction of concepts from the percepts (i.e., the minimum level necessary for rational thought) and the maximum level of complexity attainable by evolutionary processes.

\subsection{The Nature of the Two Points}

What is the minimum level of perceptual complexity necessary for the abstraction of concepts? Mivart $(1876,189)$ referred to a "faculty of collecting, grouping, and preserving sensible images of objects in complex and coherent aggregations," which seems about right. To get the concept of a triangle, we need to group diverse three-angled figures-equilateral and isosceles, acute and obtuse, large and small-and to differentiate them from, say, circles and rhombi. To get the concept of a horse, we need to group Bucephalus, Dan Patch, and Clever Hans-the war-horse, race-horse, and circus-horse, and to distinguish them from donkeys and zebras. For mammals-we need to group dogs and horses, opossums and platypodes, and even dolphins and bats, differentiating them from sharks and robins. From what would a being without such a faculty be able to abstract concepts? What more would a being with such a faculty need?

What is the maximum level of perceptual complexity which evolutionary processes can produce? To see how much complexity those processes have produced, we need to turn to ethology. That science of animal behavior has flourished in the last half-century; many ingenious experiments have deepened our understanding of animal cognition. We find capacities that lay the foundation for, even though they do not themselves exemplify, conceptualization, judgment, and reasoning.

First, there are animal mental capacities that lay the foundation for conceptualization. One is the capacity for the comparison and differentiation of images. Surely any being with sense powers at all has some ability to sort out what it sees. Dogs learn to recognize porcupines and skunks and to leave them alone. Dorothy L. Cheney and Robert M. Seyfarth (1990) have shown that vervet monkeys distinguish snakes, eagles, and leopards, making 
distinct warning calls depending on which is observed. Animals can compare an image of what is present to remembered images and act on the basis of previous experience. Another is a capacity for the association and grouping of images. Ron Schusterman (2002) taught his experimental subjects, sea lions, to sort the symbols he showed them into two groups ("numbers" and "letters") and then to assign new symbols to one group or the other on the basis of matching-to-sample exercises. The seals were able, that is to say, to construct functional equivalence classes, though not, of course, really classes that they recognized as numbers and letters. A third is the capacity for a kind of abstraction, not of concepts, of course, but a capacity to ignore particularities. The determination of numerosity can remain constant despite "variation in object features (such as size, color or shape), spatial location, modality (auditory or visual) and mode of presentation (simultaneous or sequential)" (Dehaene 1998, 356). For example,

a rat trained to press a lever on the left in response to two flashes or two sounds, and a lever on the right in response to four flashes or four sounds, spontaneously pressed the right lever when presented with a combination of two sounds and two lights. The rat's behavior was based on the abstract total number of four events, not on modality-specific representations. (Dehaene 1998, 357, summarizing Church and Meck 2014)

Second, animals have mental capacities that lay a foundation for judgment. They have a capacity for expectation. When a dog chases a cat up a tree, it knows that the cat is in the tree, in the sense of having some kind of image of that cat in that tree. Many preferential-looking experiments confirm that animals associate some of what they see happen with an expectation of what will happen next. This can be seen in explorations of what has been called number sense (Dehaene 1997, ch. 1). In one experiment, wild rhesus monkeys looked longer during presentations that violated the laws of addition than during those that were consistent with those laws. Concretely, they recognized the discrepancy between the number of eggplants that were placed into a screened box (e.g., two) and the number of eggplants that were present once the screen was removed (e.g., one) 
(Hauser 1996). ${ }^{21}$ Another foundation for judgment can be seen in Irene Pepperberg's results with an African grey parrot, Alex (1999). When shown collections of objects that varied in shape, color, and material, Alex could answer not only simple questions such as "What color?" but also "How many red keys?" and even "What's different?"

Third, there is even evidence of capacities that lay the foundation for inferential reasoning. Brendan McGonigle \& Margaret Chalmers (1977) showed that squirrel monkeys could solve transitivity problems using five-member series. Taught to choose between adjacent pairs $(\mathrm{a}>\mathrm{b}, \mathrm{b}>\mathrm{c}$, \&c.), they extend their preferences to non-adjacent pairs (e.g., $a>c$ ) which they had not been taught. Later pigeons and rats were also shown capable of doing so. This maps transitive inference (thence the name), but can be explained as a simple assignment of degrees of value-very desirable, somewhat desirable, better than nothing, etc. (Wynne 2004).

In determining the significance of these results, we must respect Lloyd Morgan's Canon, the ethological application of Ockham's Razor:22

In no case may we interpret an action as the outcome of the exercise of a higher psychical faculty, if it can be interpreted as the exercise of one which stands lower in the psychological scale. (Morgan 1894, 53)

It forbids us from using the experiments mentioned above as evidence of conceptual thought in animals in the Thomistic sense of the word. We can distinguish the categories (not in the Aristotelian sense) which are within the reach of animals from concepts as follows:

${ }^{21}$ Hauser acknowledged that the behavior of the monkeys might be explained by high-level perceptual, rather than arithmetic representations ("Perceptual representations [might] retain information about previously seen objects even when they become temporarily occluded and [...] such representations may be rich enough to encode and distinguish between several such occluded objects at once."), but even on the arithmetic explanation, the behavior does not require the abstraction of concepts-not of one or two and certainly not of addition, operation, or commutativity.

22 The application had already been made some two years before, by Wilhelm Wundt (1892, 380; trans. 1912, 350): "recourse [may] be had to complex principles of explanation [only] when the simpler ones have proved inadequate." 
a category [...] is an ability merely to discriminate a certain thing, or kind, or property-for example, a colour, or shape-as opposed to a concept, which involves a richer ability, not only perhaps to make certain discriminations, but also to reason about the thing and its relations to other entities of similar or different appearance or function, for example, to infer that something is coloured and spatial from the fact that it is red. (Rey and Hauser 2005)

The cognition of categories suggests that evolutionary processes have brought animals some way towards the kind of complexity that is prerequisite to conceptual thought.

\subsection{Their Location-I: What de Filippi \& Mivart Require}

On the question of where these two points are relative to one another, we can distinguish several possibilities.

The more fully evolutionary views posited by de Filippi and Mivart require that evolutionary processes be able to produce sense-powers at least complex enough to allow the abstraction of concepts. In other words, that abstraction needs no complexity beyond the reach of mutations and perhaps no more than would be useful to a brute animal.

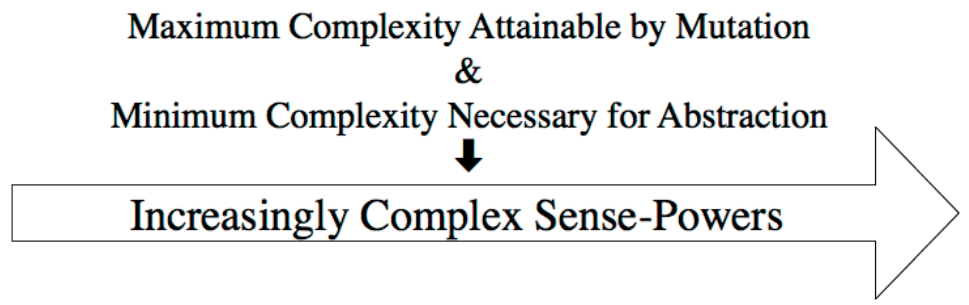

Jesuit entomologist Felix Rüschkamp (1939, 384-85) seems to have held this view:

The difference between man and animal lies not in the bodily [Animalisch], but only in the mental [Geistig] [aspects of his nature]. Our mind [Verstand] requires, for the formation of abstract concepts, sense-perception and sensory 
centers [in the brain], but nothing different from what animals (as beings with sense powers only) [reine Sinneswesen] already have. Consequently, any creative intervention or patching up of the human body or brain would be superfluous.

Since that level of complexity is only necessary and not sufficient for rational thought, that would not be sufficient to show that rational beings (such as man) could have evolved by natural processes alone. Rational beings would appear only with the creation of rational souls capable of actually doing the abstraction that their evolutionarily formed brains made possible.

Would beings with that level of perceptual development in any sense require rational souls ${ }^{23}$ Since the rational souls have to be created by God, the doctrine of Divine Freedom rules out anything like natural necessity here. There could, however, be a necessity of end. ${ }^{24}$

A rational soul might be necessary for individual survival if a mutation so changed an animal's sensitive powers that the animal could no longer function well (or perhaps at all) unless it also had a rational soul capable of abstracting concepts from the images in its mind. Since human beings do, however, still have sense-powers on which we rely in a way seemingly not dependent on our awareness of concepts, this logical possibility does not seem promising.

Could such a soul be necessary in a weaker sense? A new degree of perceptual complexity might not be of much use if it were not supplemented by an intellect; it might produce too little advantage to be favored by natural (or sexual) selection. If, by contrast, the augmented sense-powers supplemented by rational powers did offer a selectable advantage, then the augmented powers might be selected in a way that would spread through

23 Ludwig Lercher ([1940]; 1951, 296) raised this question in the third edition of his Institutiones Theologicæ Dogmaticæ. (Lercher died in 1937; this posthumous edition was, according to Motherway (1944, 217n4), revised by Franz Lakner.) He distinguished two versions of Catholic evolutionism-one according to which evolution made an animal body not only similar to a human one but organized in such a way as to require [exigit] the infusion of a rational soul and another, according to which evolution made an animal body only similar to a human one but not organized in such a way as to require the infusion of a rational soul, in which case the final modification of the human body would be the result of direct divine action. The sense of exigency central to his distinction seems not to be quite the same as the necessity in my own treatment of the idea.

24 For Aquinas distinction of three kinds of necessity, see 1273, 1a, 82.1. 
the population and thereby transform the entire species. So, the rational soul would be necessary for the spread of the new degree of perceptual complexity to the entire population.

Finally, an animal which had sensitive powers more developed than an animal would ever need, or could even use, in the course of an animal life might be able to live a full canine, simian, or cetacean life with its merely sensitive soul, but would have an untapped potential if it did not have a soul also capable of abstracting concepts from the images which its sensitive soul produced. The infusion of rational souls into such beings would be possible (in the way that would not be possible in the case of a plant) and fitting (in the sense that it would allow those animals to make a fuller use of their sense-powers).

Such fittingness would not, however, in any sense require that God actually create a rational soul for every animal body developed enough to make such infusion possible. There might be reasons why God would choose not to do so. Perhaps it sufficed for God's purposes that only some of the animals with cognitive capacities developed enough to permit the infusion of rational souls would be converted into rational animals, just as it evidently sufficed for his purposes that only some mammalian lines developed into dogs and dolphins, while others were condemned to develop only into donkeys and cats. My account of monogenesis (Kemp 2011) fits quite naturally with this idea of selective infusion.

It is also possible, of course, that mutations and selection could take a species beyond the minimum amount of complexity necessary for abstraction, or even that it has done so.

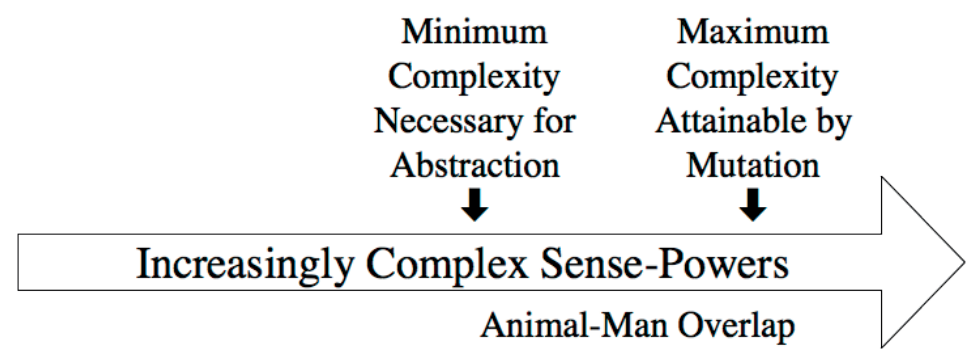

ScientiaetFides $8(2) / 2020$ 
This possibility raises a few other questions.

Question 1: Have any brute animals that have ever existed had sense-powers sufficiently complex to allow the abstraction of concepts, even though none have the rational soul necessary to effect such an abstraction? Mivart added to the characterization mentioned above, "[...] to a degree much greater than any other animal with which we were before acquainted," but was he correct? Could God have given dogs, apes, dolphins, or parrots, as they now exist, rational souls? Is it just a contingent fact that He did not actually do so?

Question 2: Are there, beyond the minimum level of complexity sufficient for concept-abstraction, degrees of increasing complexity that can be correlated with levels of intellection? The alternative would be that, once the aggregations of images reached a certain degree of complexity and coherence, no greater degree would enhance the power of abstraction.

The answers to these questions, interesting as they might be, would not affect the resolution to the more fundamental question being asked here.

\subsection{Their Location-II: What is Enough for Wallace \& González}

Perhaps, however, evolutionary processes cannot get to the minimum level of complexity necessary for abstraction of concepts, leaving the gap between animal and man unbridgeable by evolutionary processes, in which case the proper diagram would be this:

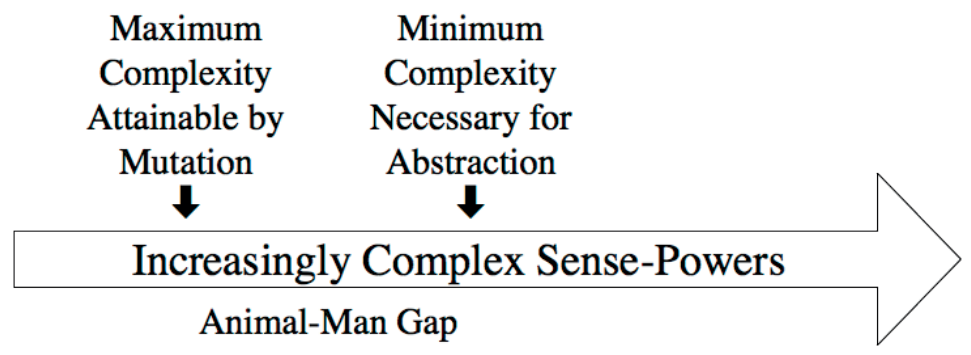


If that gap exists, divine intervention of the kind Wallace and González suggested would be one way that it could be crossed. Such intervention was defended by Juan González Arintero (1898, 188-191), by Ernest Messenger (1930, 276-280), and by Pierre Marie Périer (1938, 232-39).

It is hard to see how there could be any scientific arguments against the idea that direct divine action played some role in the formation of Adam's body. There is no evidence on the question of what in fact caused any particular past mutation. Whether God caused it directly, or whether He caused it indirectly (by causing radiation to effect it), or whether it was caused by fully natural processes is a question the data to answer which we will never have.

\section{The Two Catholic Accounts \& the Interbreeding Hypothesis}

What connection do these ideas have with my earlier paper on monogenesis (Kemp 2011)? Are both of the versions of Catholic evolutionism discussed above compatible with the Interbreeding Hypothesis which I proposed a few years ago? The deFilippi-Mivart family of views clearly is so. It was the kind of evolutionism which I had in mind. Are my earlier ideas also compatible with the Wallace-González version?

It might seem that they are not. The formation in question would presumably have to be more than just the formation of Adam's own body. It must have an effect that would be transmitted to all of his fully human descendants as well. All fully human beings, that is to say, would, on the simplest hypothesis, have to be genetic descendants of Adam (carrying, that is to say, the genes that were the product of the divine intervention), not merely his genealogical descendants. In other words, it would not be enough that all fully human beings have Adam in their family tree, they would also have to have the crucial genes in their personal genome. ${ }^{25}$ Genetic descendants are merely a subset of genealogical descendants. Universal genetic ancestry could

25 On a more complex alternative, the divinely produced mutation might subsequently be supplemented by a naturally produced mutation that first duplicated the work of the divinely produced mutation and then replaced it. 
not be achieved as quickly as can universal genealogical ancestry. Either of two factors could, however, make the spread of the crucial genes to all humanity, even to the isolated populations living at the ends of the earth, sufficiently rapid to meet all theological, scientific, and historical concerns. ${ }^{26}$ The first such factor is that rationality might be sufficiently favored by natural or sexual selection to spread fairly rapidly through populations of reproductively human beings. The second is that the first rational beings might have lived so long ago that even a more slowly-spreading mutation could have reached all reproductively human beings long enough ago to obviate this problem. There may be no reason to posit direct divine action in the formation of Adam's body, but the fact of such action, if fact it be, would not undermine the Interbreeding Hypothesis on which I relied to meet the objection to monogenesis on the basis of human genetic diversity.

\section{Eve}

Let me conclude with some remarks about the body of Eve. There are three reasons why this matter requires separate attention.

First, of course, the narrative of Genesis distinguishes Adam (formed from dust) from Eve (formed from the rib- הצלע hașs êlā -of Adam). The Pontifical Biblical Commission, in its statement of 1909, handled the two cases slightly differently: "Whether in particular the literal historical sense can be called into question where it is a matter of facts (presented in those chapters) pertaining to the foundation of the Christian religion; for example, [...] the distinctive creation of man [and] the formation of the first woman from the first man [...] - It cannot." In what way was "the formation of the first woman from the first man" a "fact [...] pertaining to the foundation of the Christian religion"? St. Thomas (1273, 1a, 92.2) gave four reasons. Here are two: "In order thus to give the first man a certain dignity consisting in this, that as God is the principle of the whole universe, so the first man, in likeness to God, was the principle of the whole human

26 On this, see the first chapters of Swamidass (2019). 
race," and, a sacramental reason, "by this is signified that the Church takes her origin from Christ."

Second, some Catholic anti-evolutionist theologians have tried to use the thesis of divine action in the formation of the body of Eve as a kind of Archimedean point against the hypothesis of the evolutionary origin of the body even of Adam. Gerard Van Noort, for example, wrote that "No thoughtful person thinks that, the body of Adam having been formed by evolution, the body of Eve was not" $(1912,115)$. He was wrong. Some thoughtful people, including leading Catholic evolutionists such as Henry de Dorlodot (2009, 159-179) and E. C. Messenger (1932, 252-273), thought just that. Perhaps Van Noort just meant that they should not have done so.

How did those evolutionists handle a third, largely scientific, concern? The infusion of rational souls into two individuals out of a population of prehuman beings would not be sufficient to address the theological concerns of the Pontifical Biblical Commission. Neither natural mutation in two individuals, ${ }^{27}$ nor even divine modification of those two would yield quite the dependence of Eve's body on Adam's indicated above. Messenger, in particular, wrestled with the search for some natural process that would involve such dependence, but in the end noted that "this difficulty did not hinder the Fathers or the ancient doctors and theologians, except Cajetan, from accepting the doctrine" $(1932,273)$.

That God would use extra-natural processes when necessary to achieve his theological ends, while in other cases relying on the natural powers of beings which He had already made, can be established on other grounds. That He who did so at Cana might also have done so in Eden is not so very improbable. That He used Adam's rib is surely not impossible. That detail might, however, be needlessly offensive to scientific ears. So as a matter of delicacy, let me suggest an alternative not at all far removed from Scripture

27 Any account which relies exclusively on a genetic difference between Adam and Eve, on the one hand, and the other individuals in the species from which they evolved will face, in addition, this trilemma. If the genetic mutation underlying the difference occurred less than twice, then Adam and Eve did not share it. If it occurred more than twice, then there are human beings who are not their descendants. That natural processes produced it exactly twice seems improbable. It is not, to be sure, impossible. 
and not forcing any revision of the theological doctrines connected to the passage in question.

First, what exactly does הצלעs has $\bar{a}^{\text {a }}$ mean? Is it exactly a rib? Or is it just something taken from Adam's side? Could it be a small strand of DNA transplanted from Adam into Eve at the moment of her conception? There being no word for DNA in Biblical Hebrew, how would that fact have been הצלע revealed to the author of Genesis or transmitted to its readers? Maybe would seem to be as good a choice as any. This strand would not have to be the genetic marker of humanity and would not have to be passed on to all of the human descendants of Adam and Eve. The conservative theological requirement is only that Eve have been formed from the body of Adam and everyone else genealogically descended from them. No one thinks that Eve passed on the transplanted rib, so there is no reason to think that she passed on to all (or even any) of her descendants the transplanted genes either.

\section{Conclusion}

There is no reason to think that evolutionary processes cannot reach a level of perceptual complexity sufficient to allow the abstraction of concepts. It is not necessary to think that the construction of the body of a rational animal must begin from scratch. Animal behavior does show a modest ability to "collect, group, and preserve sensible images of objects, but it does go far enough " in the direction of "complex and coherent aggregations" to make plausible the idea that bodies with perceptual powers equivalent to those found in man might have been formed by purely evolutionary processes.

The principles of Christian naturalism articulated by Henry de Dorlodot (1921, 108 and 115; 1925, 87 and 93-94) a century ago suggest a presumption in favor of the natural evolution of the body of Adam, but even if the full attainment of the required level of complexity is beyond the reach of evolutionary processes, surely the product of those processes is close enough to allow completion by modest divine supplementary modification of an animal that is itself the product of evolution. 


\section{References}

Arintero, Juan González. 1898. La Evolución y la Filosofía Cristiana: Introducción General. Madrid: Librería de Gregorio del Amo.

Aquinas, Thomas. 1273. Summa theologiae.

Augustine, Aurelius. 415. De Genesi ad Litteram. Translation: 1982. The Literal

Meaning of Genesis by John H. Taylor. New York: Newman.

Bever, Lindsey. 2019. "Why Two Orphaned Gorillas Stood Tall Like Humans in a Park

Ranger's Selfie.” Washington Post, April 23.

Börsenblatt für den deutschen Buchhandel und die mit ihm verwandten Geschäftszweige.

1860. Leipzig, 27:52:683, 27:53:874, and 27:74:1166.

Boyer, Charles. 1952. “De l'Évolutionnisme anthropologique.” Laval théologique et philosophique 8:2:203-7.

Bronn, Heinrich Georg. 1860. Über die Entstehung der Arten im Thier- und Pflanzenreich. Stuttgart: Schweizerbart.

Buonpensiere, Enrico. 1898. Votum on John Zahm's Evolution and Dogma, April 15. Protocolli, 1897-1899, fol. 180, 40-1. Archive of the Congregation of the Doctrine of the Faith

Chambers, Robert. 1844. Vestiges of the Natural History of Creation. London: Churchill. Cheney, Dorothy L., and Robert M. Seyfarth. 1990. How Monkeys See the World: Inside the Mind of Another Species. Chicago: University of Chicago Press.

Church, R. M., and W. H. Meck. 2014. “The Numerical Attribute of Stimuli.” In Animal Cognition, edited by H. L. Roitblat, T. G. Bever, and H. S. Terrace, 445-64. London: Psychology Press.

Cologne, Council of. 1860. "Decreta Concilii a Sancta Sede Recognita”. In Acta et decreta sacrorum conciliorum recentiorum; Collectio Lacensis, 5:269-382. Freiburg: Herder. 1879.

Darwin, Charles. 1859. On the Origin of Species. London: Murray.

Darwin, Charles. 1860. On the Origin of Species, 2d ed. London: Murray.

Darwin, Charles. 1872. On the Origin of Species. 6th ed. London: Murray.

Darwin, Charles. 1871. The Descent of Man. London: Murray.

Darwin, Charles. 1874. The Descent of Man. 2d ed. London: Murray.

De Dorlodot, Henry. 1903. “De mente Concilii Viennensis in definienda informatione corporis humani ab anima rationali.” In Quaestionum quodlibetalium, 69-106. Louvain: Uystpruyst-Dieudonné.

De Dorlodot, Henry. 1921. Le Darwinisme au point de vue de l'orthodoxie catholique. vol. 1: L’Origine des espèces. Brussels: Vromant. Translation: 1925. Darwinism and Catholic Thought by Ernest C. Messenger. New York: Benziger.

De Dorlodot, Henry. 2009. L'Origine de l'homme. Brussels: Mardaga. 
De Filippi, Filippo. 1864. "L’Uomo e le scimie.” Il Politecnico: Repertorio mensile di studj applicati alla prosperità e coltura sociale 21:5-32.

De Filippi, Filippo. 1864. L'Uomo e le scimie. Milan: Daelli.

De Filippi, Filippo. 1865. L'Uomo e le scimie, 3d ed. con aggiunte dell'autore. Milan: Daelli.

Dehaene, Stanislas. 1997. The Number Sense. New York: Oxford University Press.

Dehaene, Stanislas, Ghislaine Dehaene-Lambertz, and Laurent Cohen. 1998. "Abstract Representations of Numbers in the Animal and Human Brain." Trends in Neuroscience 21:8:355-61.

Descartes, René. 1641. Meditationes de prima philosophia. Translation: 1931. Meditations on First Philosophy by Elizabeth S. Haldane and G. R. T. Ross. In The Philosophical Works of Descartes, 1:131-200. Cambridge: Cambridge University Press.

Frohschammer, Jakob. 1854. Über den Ursprung der menschlichen Seelen: Rechtfertigung des Generationismus. Munich: Rieger.

González, Zeferino. 1892. La Biblia y la Ciencia, 2d ed. Seville: Izquierdo.

Gould, Stephen J. 1980. “Natural Selection and the Human Brain.” In The Panda's Thumb, 47-58. New York: Norton.

Gregory of Nyssa. 379. Perì Kataskeuî̀ A’nthrốpou. In Patrologia graeca, ed. by J.-P. Migne (1863), 44:123-256. Translation: 1917. On the Soul and the Resurrection. In Nicene and Post-Nicene Fathers, Series 2, edited by Philip Schaff and Henry Wace, 5:387-427. New York: Scribner's.

Gregory of Nyssa. 380. Perì Psychî̀s kaì A’nastáseōs. In Patrologia graeca, ed. by J.-P. Migne (1863), 46:11-160. Translation: 1917. On the Making of Man. In Nicene and Post-Nicene Fathers, Series 2, edited by Philip Schaff and Henry Wace, 5:430-468. New York: Scribner's.

Hauser, M. D., P. MacNeilage, and M. Ware. 1996. "Numerical Representations in Primates.” Proceedings of the National Academy of Science USA (February 20) 93:4:1514-7.

Hedley, John Cuthbert. 1898. “Physical Science and Faith.” Dublin Review 4:28:241-61. John Paul II. 1996. “Ad Pontificiae Academicae Scientiarum Solidares.” In Acta Apostolicae Sedis (1997) 89:186-90. Translation: 1996. “Revised Translation of Pope's Message on Evolution to the Pontifical Academy of Sciences.” In Origins: CNS Documentary Service 26:25:414-16.

Kemp, Kenneth W. 2011. “Science, Theology, and Monogenesis.” American Catholic Philosophical Quarterly 85: 2:217-236.

Lateran Council, Fifth. 1513. Apostolici regiminis. In Conciliorum Ecumenicorum Decreta, 1962, edited by J. Alberigo, G. A. Dossetti, P. P. Joannou, C. Leonardi, and P. Prodi, 581-585. Freiburg: Herder. 
Lercher, Ludwig. 1940. Institutiones Theologicæ Dogmaticæ: II. De Deo Creante, 3rd ed. Innsbruck: Rauch.

Lercher, Ludwig. 1951. Institutiones Theologicæ Dogmaticæ: II. De Deo Creante, 5th ed. Innsbruck: Rauch.

Lyell, Charles. 1869. “On Geological Climates and the Origin of Species.” Quarterly Review 126: 359-94.

McGonigle, Brendan, and Margaret Chalmers. 1977. “Are Monkeys Logical?” Nature 267: 694-6.

Messenger, Ernst. 1932. Evolution and Theology. New York: Macmillan.

Mivart, St. George Jackson. 1876. Lessons from Nature as Manifested in Mind and Matter. London: Murray.

Mivart, St. George Jackson. 1871. On the Genesis of Species. London: Macmillan.

Moleschott, Jacopo. 1866-67. “Cenno Biografico sul socio prof. Filippo De Filippi / 7 apr. 1867.” Atti della Reale Accademia delle scienze di Torino 2: 431-453.

Morgan. C. Lloyd. 1894. Introduction to Comparative Psychology. London: Scott.

Motherway, Thomas J. 1944. “Current Theology: Theological Opinion on the Evolution of Man.” Theological Studies 5:2:198-221.

Pepperberg, Irene Maxine. 1999. The Alex Studies. Harvard: Harvard University Press.

Périer, P. M. 1938. Le Transformisme: L'Origine de l'homme et le dogme catholique. Étude apologétique. Paris: Beauchesne.

Pierre-Julien Hamard. 1889. “Transformisme.” In Dictionnaire apologétique de la foi catholique, edited by Jean-Baptiste Jaugey, 3087-3104. Paris: Delhomme et Briguet.

Pontifical Biblical Commission. 1909. "De Charactere historico trium priorum capitum geneseos.” Acta Apostolicae Sedis 1:567-9.

Rey, Georges, and Marc Hauser. 2005. “Animal Thought, Recent Work on.” In Routledge Encyclopedia of Philosophy. Taylor and Francis. doi:10.4324/978041 5249126-V039-1

Rosmini-Serbati, Antonio. 1858. Psichologia. Rome: Miglio. Translation: 1999. Psychology, Vol. 1: Essence of the Human Soul by Denis Cleary and Terence Watson. Durham: Rosmini House.

Ruffini, Ernesto. 1948. La Teoria dell'evoluzione secondo la scienza e la fede. Norcia: Orbis Catholicus. Translation: 1959. The Theory of Evolution Judged by Reason and Faith by Francis O’Hanlon. New York: Wagner.

Rüschkamp, Felix. 1939. “Der Mensch als Glied der Schöpfung.” Stimmen der Zeit $135: 6: 367-85$.

Scheeben, Matthias Joseph. 1873-1887. Handbuch der katholischen Dogmatik. Freiburg: Herder. 
Schusterman, Ronald J., C. R. Kastak, and D. Kastak. 2002. “The Cognitive Sea Lion: Meaning and Memory in the Laboratory and in Nature.” In The Cognitive Animal: Empirical and Theoretical Perspectives on Animal Cognition, edited by M. Bekoff, C. Allen, and G. M Burghardt, 217-228. Cambridge: MIT Press.

Sillem, Edward, ed. 1969-1970. The Philosophical Notebook of John Henry Newman. Louvain: Nauwelaerts.

Swamidass, S. Joshua. 2019. The Genealogical Adam \& Eve. Downers Grove: IVP.

Tolkien, J. R. R. 1966. “On Fairy Stories.” In The Tolkien Reader, 24-109. New York: Ballantine.

Van Noort, Gerard. 1912. Tractatus de Deo Creante. 2nd ed. Amsterdam: van Langenhuysen.

Vatican Council, First. 1869. “Schema constitutionis dogmaticae” of 20 December. In Acta et decreta sacrorum conciliorum recentiorum; Collectio Lacensis (1890), 7: 71 and 108-112. Freiburg: Herder

Vienne, Council of. 1312. Fidei Catholicae Fundamento. Reprinted in 1962. Conciliorum Ecumenicorum Decreta, edited by J. Alberigo et al., 336-7. Freiburg: Herder.

Vogt, Carl. 1858. Natürliche Geschichte der Schöpfung des Weltalls, der Erde und der auf ihr befindlichen Organismen, begründet auf die durch die Wissenschaft errungenen Tatsachen, $2 \mathrm{~d}$ ed. Brunswick: Wieweg. A translation of the sixth edition of Chambers 1844.

Wallace, A. R. (anonymously). 1869. "Sir Charles Lyell on Geological Climates and the Origin of Species.” Quarterly Review 126: 359-94.

Wallace, A. R. 1870. Contributions to the Theory of Natural Selection. New York: Macmillan.

Wallace, A. R. 1875. On Miracles and Modern Spiritualism: Three Essays. London: Burns. Wasmann, Erich. 1906. Die moderne Biologie und die Entwicklungstheorie. Freiburg im Breisgau: Herder. Translation: 1923. Modern Biology and the Theory of Evolution by A. M. Buchanan. London: Kegan Paul.

Wilberforce, Samuel. 1860. Review of On the Origin of Species, by Charles Darwin. The London Quarterly Review 108: № 215:118-38.

Wundt. Wilhelm. 1892. Vorlesungen über die Menschen- und Tierseele. 2nd ed. Berlin: Voss. Translation: 1912. Lectures on Human and Animal Psychology by J. E. Creighton and E. B. Titchener. London: Allen.

Wynne, Clive. 2004. Do Animals Think? Princeton: Princeton University Press. 